\title{
Ecological inspirations for the Tourism Area Life Cycle (TALC) model
}

\author{
Ekologiczne inspiracje modelu TALC cyklu życia obszaru turystycznego
}

\author{
Wojciech Szeligiewicz \\ Faculty of Tourism and Recreation, Józef Piłsudski Academy of Physical Education in Warsaw, Poland \\ ORCID: https://orcid.org/0000-0001-5662-9033•wojwicz@wp.pl
}

\begin{abstract}
Richard Butler's Tourism Area Life Cycle (TALC) model proposes a specified view on the qualitative changes in the number of tourists $\mathrm{N}$ in the area over time and the environmental, social and economic processes taking place there simultaneously. $\mathrm{N}$ changes follow S-shaped curve up to stagnation phase. Such a course was adopted in the TALC model, assuming that the tourist population at this stage develops in accordance with a logistic model derived from ecology. This work aimed to recall the properties of the logistic model and the ecological assumptions underlying it, and some of the consequences of incorporating the logistic model into the TALC model. An attempt has also been made to link other TALC aspects with ecology. In particular, reference is made to the graph on the right side of the logistic equation of the TALC model as a function of $N$ with the phases of evolution of the tourist area marked, which reminds that the most attractive area is the original area, i.e. when $N$ is small, as it is characterized by the highest per capita growth of the tourist population. According to this figure, as $N$ increases, there is a linear decrease in attractiveness despite the investments introduced according to the TALC model scenario, i.e. they do not reverse this trend. The same diagram can be used to show some elementary differences between ecotourism and mass tourism. The issues of population regulation were also raised, including the density-dependent self-regulation, the Allee effect, the concept of environmental capacity and $r$ and $K$ strategies. It was also pointed out that the experience gained in the field of population modelling in ecology could help to model tourist populations.
\end{abstract}

Keywords: touristic area, tourists, mass tourism, ecotourism, density-dependent effects, population regulation, $r$ and $K$ strategy, TALC model

Streszczenie: Model cyklu życia obszaru turystycznego (TALC) Richarda Butlera proponuje określony obraz jakościowych zmian liczebności turystów $N$ na tym obszarze w miarę upływu czasu i zachodzących tam równocześnie procesów środowiskowo-społeczno-ekonomicznych. Zmiany $N$ aż do osiągnięcia stagnacji mają następować według krzywej esowatej. Taki przebieg otrzymany został w modelu TALC przy założeniu, że populacja turystów rozwija się na tym etapie zgodnie z modelem logistycznym, zaczerpniętym z ekologii. Celem tej pracy było przypomnienie własności modelu logistycznego i ekologicznych założeń leżących u jego podstaw oraz pewnych konsekwencji wkomponowania modelu logistycznego do modelu TALC. Podjęto także próbę powiązania innych aspektów TALC z ekologią. W szczególności powołano się na wykres prawej strony równania logistycznego modelu TALC w funkcji N z naniesionymi fazami ewolucji obszaru turystycznego, który przypomina, że najbardziej atrakcyjny jest obszar pierwotny tzn. gdy N jest małe, gdyż cechuje się on największym wzrostem populacji turystów liczonym per capita. Według tego wykresu wraz ze wzrostem $N$ zachodzi liniowy spadek atrakcyjności obszaru mimo wprowadzanych tam zgodnie ze scenariuszem modelu TALC inwestycji, tzn. nie odwracają one tego trendu. Ten sam diagram może posłużyć do pokazania niektórych elementarnych różnic pomiędzy ekoturystyką i turystyką masową. Poruszono też kwestie regulacji populacji, w tym gęstościowo-zależnej samoregulacji, efektAllee, pojęcie pojemności środowiska oraz strategii ri K. Wskazano także, że w modelowaniu populacji turystów pomocne mogą być doświadczenia zdobyte na polu modelowania populacji w ekologii.

Słowa kluczowe: obszar turystyczny, turyści, turystyka masowa, ekoturystyka, efekty gęstościowo-zależne, regulacja populacji, strategia ri K, model TALC

"This article was originally published in Polish as Szeligiewicz, Wojciech. 2017. "Ekologiczne inspiracje modelu TALC cyklu życia obszaru turystycznego." Studia Ecologiae et Bioethicae 15(4): 63-78. The translation of the article into English was financed by the Ministry of Science and Higher Education of the Republic of Poland as part of the activities promoting science - Decision No. 676/P-DUN/2019 of 2 April 2019. Translation made by GROY Translations. 


\section{Introduction}

Tourism is an interdisciplinary field of scientific research in which representatives of various sciences find areas of their own interest, as well as a reflection of theories, paradigms, and methodologies from their native areas of interest. A spectacular example of such an impact on tourism is the influence of ecological thought on the Tourism Area Life Cycle (TALC) model by Canadian geographer Richard Butler (1980). This is perhaps the most popular, most widely used and the most cited model of changes in the functioning of a tourist area for almost 40 years, also considered as 'the cornerstone in the research of tourism development' (Prideaux 2000; Casasnovas and Rosselló 2009; Rodríguez, Parra-López and Yanes-Estévez 2008; Alonso-Almeida et al. 2017). This model presents a scenario of economic, organizational and social changes taking place in the tourist area as the number of tourists grows. The change of this number over time is described by the S-shaped (also called sigmoid) curve until reaching a certain stagnant value, after which the model allows for hypothetical deviations from the achieved state. The cycle, therefore, includes the emergence of the tourist reception area, its development, maturity and regress or rebirth.

Although the literature points to the analogy of this structure to the model of the "product life cycle" and other concepts in the field of economics (Butler 2009; Butler 2011; Ma and Hassink 2013), and even to the "entropy law" (Singh 2011), however, the S-shaped curve was adapted to the TALC model from ecology. As Butler (Butler 1980) writes, "Nature's ecology and population are one of the pillars of the TALC model". The mentioned curve is, for example, a solution to the logistic equation, which belongs to the elementary equations (models) of population ecology. In fact, Butler assumed that the increase in the

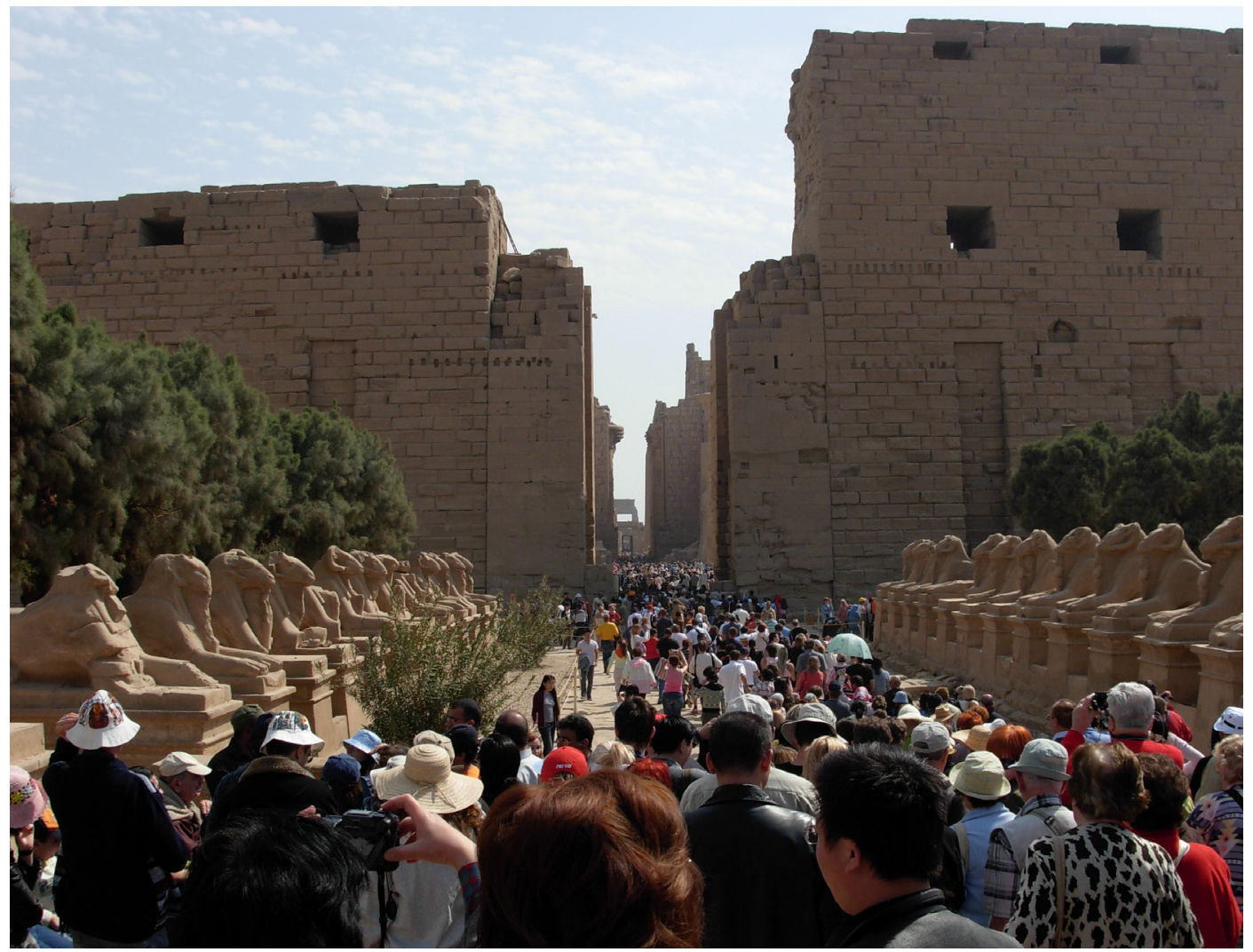

Fig. 1. The temple of Karnak as an example of a strongly tourist-loaded reception area (photo: W. Szeligiewicz). 
number of tourists in the area also follows this equation (Brougham and Butler 1972; Butler 1980). But the solution of the logistic equation is not only characterized by a sigmoid curve along with its characteristic saturation level. This solution also has other properties, which are therefore included in the TALC model. Moreover, the logistic equation requires making certain assumptions about the modelled population and the environment in which it grows.

This work aims to elaborate on this issue and recall the ecological assumptions underlying this equation as well as the properties and rationale behind this equation, as well as to show the implications for the TALC model. In general, an attempt will be made to link the TALC model with ecology.

In the beginning, it is suggested that the issues taken up when describing the tourist population may be similar to the issues that ecology deals with when studying the population of living organisms. Then, the main assumptions and properties of the logistic model and the TALC model will be recalled. Ultimately, an attempt will be made to embed the TALC model in ecological grounds and to indicate the potential benefits of the ecological theory for tourism.

\section{Tourist population in the tourist reception area}

Tourists who coexist in a given area of tourist reception form a group of people who interact with each other, as well as who have an impact on this area - the environment (habitat) and are also influenced by it. So they form a system together. In ecology, a group of people (generally - organisms of the same species) connected in this way with each other and with the environment is called a population (Hastings 1997) and form an elementary ecological system. The issues related to tourist reception areas may be spectacular, especially in the case of their significant tourist traffic load, as symbolically shown in Fig. 1.

In addition to the extraordinary architecture and the fascinating history of Ancient Egypt, the attention is drawn to the crowds of tourists present there, testify- ing to the popularity of this place. In such cases, the fundamental question (for managers, as well as for all visitors and locals who are connected with this tourist area) is why there is such a number of tourists in the area or what factors influence the popularity of this area, expressed e.g. by this number (the size of this population) or by the average number of tourists per unit surface of this area, i.e. the density of this population. Let this number or density of tourists be represented by the variable $N$. In general, the issue comes down to the question of whether $N$ is regulated by something? What processes are responsible for this? Important is also to know the dynamic of $N$ changes, i.e. about the values $\Delta N / \Delta t$ (where $\Delta$ means an increment of the considered value). This quotient expresses the rate of change of $N$. Knowing these rates and the current $N$, the value of $N$ in subsequent moments of time, e.g. next season, can be predicted. It is also possible to go deeper and connect specific phenomena and processes with a given $N$, e.g. in the tourist infrastructure and services in the tourist reception area under consideration. Shortly, the "evolution" of the tourist area can be seen through the $N$ changes. It is also natural to ask about the maximum number of tourists that this area can accommodate, $N \max$, i.e. the tourist capacity of the area. To try to find answers, one can build a model describing changes in $N$ over time, or in other words, give a recipe linking this quantity with factors influencing it.

\section{Evaluation of the number of tourists in their reception area. References to population ecology}

Approximately (when births and deaths in the area under consideration are omitted), the $N$ value will result from how large the population has been in the area so far, and from the balance between current arrivals and departures (Fig. 2). These, in turn, depends on the anthropogenic and natural values of this area, the weather, season, touristic facilities (accommodation, food, transport and accompanying facilities), 
hospitality and, more generally, mutual relations between tourists and residents and tourist service providers, advertisements, and - to go back to the example from Karnak - from the intrusiveness of flies, mosquitoes and gastrointestinal problems that often occur in hot countries. This may also take into account the population structure, such as e.g. age structure, economic status, country of origin, etc., and the fact that the $N$ value (current and in previous periods) can influence a number of factors mentioned here. The impact of the exchange rate, the global and local socio-political situations and many potential but rare factors, such as solar eclipses, locusts and other catastrophes referred to the Biblical "Egyptian Plagues", are also possible (the Nile is not flooding any more after the Aswan dam has been constructed) but will be not considered here.

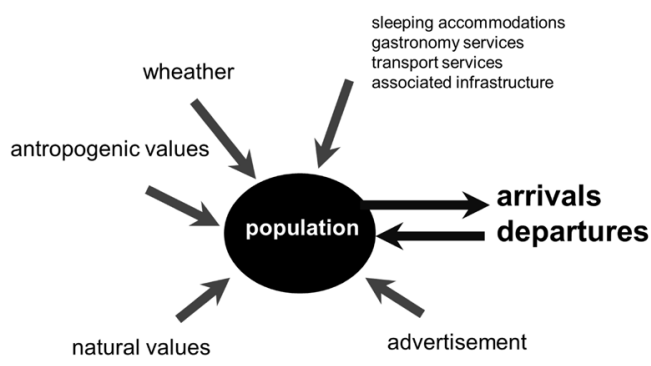

Fig. 2. Examples of factors influencing the balance of the number of tourists in the reception area.

This task can be supported by the significant achievements of the population ecology, which deals, among others, with similar problems (e.g. Uchmański 1992; Murray 2002). To compare with the example of tourists in Karnak, we can consider any population in its habitat, not necessarily people, e.g. the population of birds residing in the surrounding trees (Fig. 3). The population size of the birds may increase or decrease as a result of migration as well as births and deaths (which would be rather marginal in Karnak). The birds have a transport services in the form of favourable winds and a food base. At the same time, the trees provide them vantage points over the surrounding area, good opportunity for rest ("sleeping accommodations") and recreation with "infrastructure" in the form of nests or hollows, or convenient branches, facilitate take-offs, etc. Individuals of this population must face their competitors, predators and parasites. Moreover, this population may be characterized by a diverse structure, interactions, e.g. social ones, signals that serve the purpose of communication (through which a specific "advertisement" can be created: mutual observation that allows, for example, to find out in which direction to go in order to return with a full stomach). Moreover, individuals from this population must solve various, sometimes complex life problems. Importantly, ecologists with respect to such or other populations ask the same questions as in tourism: what determines the number or density of these organisms $(N)$ ? A relationship is sought between this number and various environmental and intra-population factors. They also ask about the dynamics of changes in $N$ and whether Nmax exists, and what they depend on.

\section{The logistic model and the ideas it contains}

A central role in such considerations in ecology was played by the so-called logistic equation (Townsend, Begon, and Harper 2003) proposed in 1838 by the Belgian mathematician Pierre-François Verhulst, which has the form:

$$
\frac{1}{N} \frac{d N}{d t}=r\left(1-\frac{N}{K}\right)
$$

where $N$ is the number of individuals in the population or size of the population (e.g. Den Boer and Reddingius 1996; Murray 2002; Chapman and Reiss 2009; Foryś 2005) or population density (Uchmański 1992; Hastings 1997), $r>0$ and $K>0$ are constant parameters of the model, $N \geq 0$, because only then $N$ makes sense as population density or population size.

Due to the special role of this equation in ecology - and as it turns out, also in tourism - it is worth recalling the basic information related to it. Its left side represents the rate of population change calcu- 


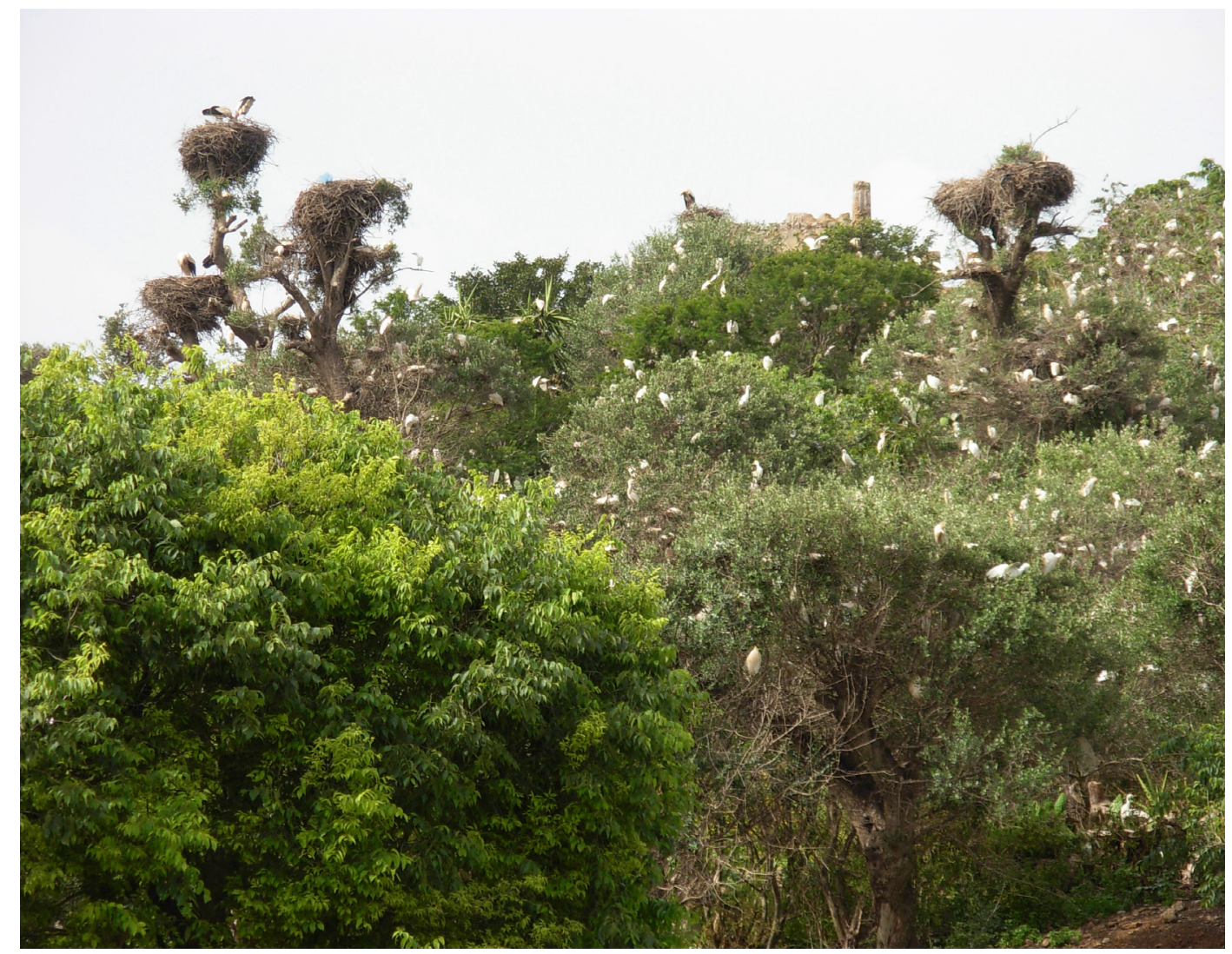

Fig. 3. Bird populations affected by similar factors as can be found for human populations (photo: W. Szeligiewicz).

lated per individual. In turn, the right side expresses this speed as a product of two factors: $r$ and $(1-N / K)$. If $r$ only was on the right, the equation would represent the well-known Malthusian Equation dating back to 1798. Despite the assumptions made in the Malthusian model, which are some approximation of the reality and as such do not give rise to any greater objection, at first sight, the solution to such an equation is, however, paradoxically unrealistic, showing exponential, unlimited population growth. In fact, such an increase is not possible (Pianka 1981), although in a short term this solution may reflect the behaviour of real populations (initially, this is how the solution of the logistic equation behaves, which will be discussed later). Against this background, a fundamental ecological question arose, what are the reasons for deviating from such a growth (Hastings 1997). Malthus suggested that when plants and animals become overcrowded, population growth is inhibited by lack of space and food (Den Boer and Reddingius 1996). He applied his reasoning also to the human population. In this case, with the growing population and depletion of resources, violent social phenomena, such as hunger, disease and wars, would appear, abruptly reducing the density of the population. The $r$ parameter can be called the maximum potential reproduction rate per individual in the population (Uchmański 1992; Den Boer and Reddingius 1996), albeit it is also sometimes called the intrinsic rate of increase or the Malthusian parameter (Rose 1987).

The observation of nature suggested that more subtle regulatory mechanisms could also operate, which would provide populations with a tendency to achieve equilibrium (Odum 1982). The convic- 
tion about the presence of such mechanisms resulted also from the equilibrium world vision that had prevailed for centuries in Western thought, i.e. "The balance of nature" (Pahl-Wostl 1995; Krebs 2011), considered as the oldest ecological theory (Egerton 1973; Pahl-Wostl 1995). This concept was subsequently underpinned in the 19th century by studying natural systems (e.g. homeostasis in physiological processes, such as maintaining adequate oxygen levels in mammalian blood through faster or slower breathing depending on physical exertion or the mechanism maintaining a constant temperature of the human body), as well as by technical inventions that appeared at that time (e.g. a steam engine with the inherent speed controller) (Den Boer and Reddingius 1996; Szeligiewicz 2010a).

The formalization of these concepts concerning the description of population growth was made by Verhulst 40 years after the publication of the Malthusian model, by adding the already mentioned factor $(1-N / K)$ to the above equation. This factor represents the population size regulation paradigm (Den Boer and Reddingius 1996), which ensures that the population neither perishes nor reaches a size beyond its possible limits. This regulation is implemented here through the population feedback mechanism (Den Boer and Reddingius 1996). Mathematically, the simplest mechanism of density-dependent regulation (Rose 1987) in the form of a linear function of $N$ is used here. The factor $(1-N / K)$ reduces the value of $r$. The highest value of this factor is equal to 1 for $N=0$, so with small $N$, the population increases exponentially with a maximum speed per capita equal to or close to $r$. With an increase in $N$, the value of the factor $(1-N / K)$ decreases, hence the population growth slows down. When $N$ reaches the $K$ value, the value of the factor $(1-N / K)$, and thus the righthand side of the equation will approach zero - the population will stop growing, so $N=K$ is an equilibrium value. On the other hand, when $N>K$, then the factor
$(1-N / K)$, and hence the right side of the logistic equation has negative values. The population size $N$ is decreasing. When $N$ reaches the value of $K$, then, as before, the population will stop shrinking. At $N=K$, the population size is balanced. Moreover, $N=K$ is a state of stable equilibrium, because if $N \neq K$, then $N$ always follows - as mentioned above - the value of $K$ as long as $N>0$ at the beginning. Put simply, a population limits its growth as it approaches the capacity of the habitat, and decreases as it exceeds that capacity. So it's self-regulated. Thus the solution to this equation is S-shaped. Nicholson (Nicholson1954; Odum 1982) called this type of growth "growth conditioned by density". The $N$ of the population tends asymptotically to equilibrium $N$ equal to $K$ over time (or $N$ remains equal to $K$, if previously it was). The population growth was therefore limited to the value $K$.

Limiting population growth is interpreted here as the occurrence of some "environmental resistance" which grows with $N$ (Chapman 1928; Vandermeer and Goldberg 2003) or "harmful environmental factors", which are for example caused by organisms themselves (Odum 1982), or the growing competition between individuals of this population for environmental resources (Nicholson and Bailey 1935; Vandermeer and Goldberg 2003; Foryś 2005), which would lead to an increase in mortality and/or a decrease in reproduction. Ultimately, with $N=K$, the balance between the two processes is established. Therefore, this equilibrium depends on the value of the $K$ parameter, which is called the "carrying capacity". On the other hand, the second parameter of this equation $r$ influences the speed of $N$ approaching $K$ (Uchmański 1992; Murray 2002). The greater $r$, the higher the speed (Uchmański 1992).

This model, due to its simplicity and the inclusion of a certain pattern of behaviour in several different populations, is still frequently used today as an element of more complex mathematical constructions in population ecology (Murray 2002). It can also be found in most textbooks in ecology. 
The logistic model was described by Verhulst himself (Verhulst 1838; Vandermeer and Goldberg 2003) and by Doubleday (Doubleday 1841; Den Boer and Reddingius 1996) as the "true law of population". Similarly, Raymond Pearl, who "rediscovered" the logistic equation (Odum 1982), called it an almost "universal law of population growth" (Murray 2002).

Verhulst's model contains several simplifying assumptions. Namely, time is continuous in this model: individuals are born and die at any moment. Population growths immediately adjust to the current population density. So there are no time delays. There is no population structure taken into account. There are no explicitly included individuals or differentiation between them - they are treated collectively and hidden under one number characterizing the size or density of a population. Population growth (with constant $r$ and $K$ ) depends on the population size or the density only. Interactions with other populations are not explicitly considered. There is no overt interaction with resources or other environmental factors - the environment is characterized by constant $r$ and $K$ parameters (although this does not mean that the environment is constant, if only because, as the population grows, the environment is increasingly "resisting", or that resources are more and more difficult to access, and the population may change the living conditions in the environment). At the same time, the same constant parameters $r$ and $K$ and the third parameter, which is the initial density, characterize the described population (e.g. in an identical environment, different populations may correspond to different $r$ and $K$ ). There is no migration of individuals. There is no explicit space, its heterogeneity and the size of the area occupied by the population (e.g. in fact, with a larger area, even despite the same $N$ density of the same individuals, the interactions between individuals from opposite fringes of the area will probably be different than between individuals inside the local sub-area, so the population as a whole will behave differently). However, thanks to these simplifications, the model retains its simplicity and is easy to analyse and interpret. In fact, a large part of the classical mathematical ecology is based on similar simplifications (for descriptions of these models, see, for example, Uchmański 1992; Murray 2002). And in many cases, the above model captures the essential nature of the relation between population growth and its density.

\section{TALC model}

The TALC model (Butler 1980) describes the qualitative changes in the number of tourists $N(t)$ over time in the tourist reception area and provides characteristic, identifiable processes and phenomena that occur there along with these changes and which are, as one could even say, responsible for those changes. This would explain why the name of the model contains the term "the model of tourism area life". This means that the model not only describes changes in the size of the tourist population but also - or perhaps most of all analyses the environment with which it is connected (biotope). To emphasize this intention, when discussing the TALC model in literature, the phrase "tourism area... evolution" is used. The measure of evolution in the model - due to difficult access to other indicators - is the number of tourists (Butler 2009), which may be represented by the number of guest rooms, number of visits, etc. (Cole 2012). States or phases of phenomena and processes occurring in the tourist area are assigned to phases of the S-shaped curve (Fig. 4a). These processes explain first the acceleration, then the slowdown, and finally cessation of the growth of this curve. So it seems that they "regulate" the $N$ changes and vice versa. Such a procedure could be understood as a verbally expressed density-dependent mechanism of regulating the tourist population that leads to the steady-state of this population. This brings to mind the logistic model.

In the TALC model, there is also a final, less precise, hypothetical and somewhat 
a)

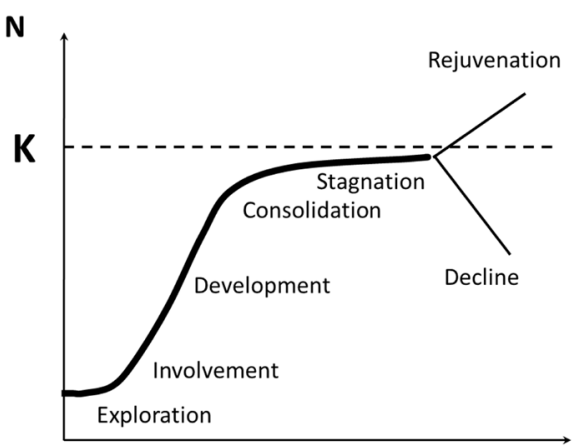

b)

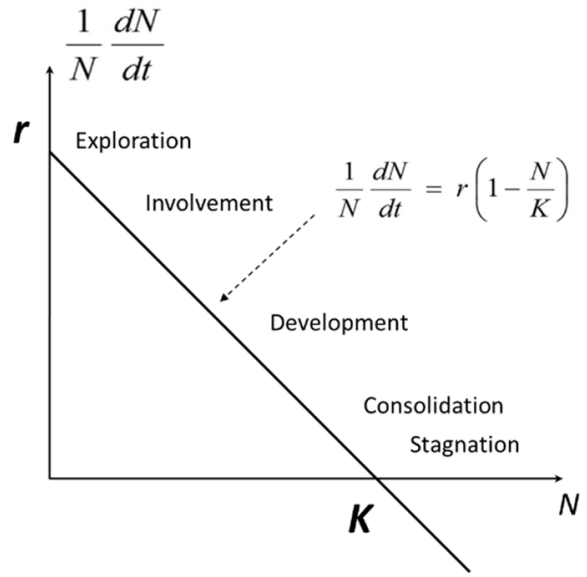

a) It is composed of a sigmoid curve showing variations in the number of tourists $(N)$ in the tourism area over time $t$ and of hypothetical curves symbolizing an increase or decrease in $N$ the number of tourists following stagnation stage of the sigmoidal curve. Besides, the model provides a pattern of chronological processes occurring in the area at that time. Their names are assigned to respective sections of the graph. The dotted line indicates the level of carrying capacity $K$ (based on Butler 1980).

b) Graph of the right-hand side of the logistic equation in the form of a descending half-line crossing the $N$ axis at $K$, and originating on the axis $1 / N(d N / d t)$ at point $r$. Corresponding parts of this line on the section $[(0, r),(K, 0)]$ were assigned to the phases of the processes from Fig. $4 \mathrm{a}$

\section{Fig. 4. Butler's Tourism Area Life Cycle model (TALC).}

mysterious downward (or upward) phase (Fig. 4a), which will be discussed later.

Lundtorp and Wanhill (2001) showed that the sigmoid curve used in the TALC model can be obtained from a logistic equation assuming that it will describe "a group of people acquiring knowledge about a tourist area (thus becoming tourists in this area)". Also, the author of the TALC model, Richard Butler (2006), coming back to the roots of the TALC model, admitted (although he referred to a lesser-known publication by Brougham and Butler 1972) that the basis for adopting a sigmoid curve in it for tourist density as a function of time in the area of tourist reception was the solution of the following logistic equation:

$$
\frac{1}{N} \frac{d N}{d t}=p(K-N)
$$

where $p$ is the "telling rate", i.e. the rate of disseminating information about the area from tourists to potential tourists (but it is also worth noting that this parameter could also be linked to the broadly under- stood measure of environmental quality, and thus to the tourists' satisfaction). In this equation, therefore, there is a density-dependent (or, in this case: congestion or crowding, Cole 2012) population size regulator (the term in parentheses on the right side of equation (2)), thanks to which (without reference to the analysis of phenomena and processes at individual stages in the area) the graph of the solution of this equation has a sigmoid shape. The tourist population at $N=K$ is balanced and stable (at $N=0$ there is an unstable equilibrium). Mathematically, this is the same equation as (1) if one puts $p=r / K$ in this equation. Therefore, in most cases, there will be references to equation (1) later in the paper.

It is worth noting that the above logistic equation (2) pretends to describe complex economic, psychological, social and natural processes in the area of reception. Many entities participate in the "life" of the area, e.g. tourists and tourism service providers, and the actual density-dependent effect does not only express a competition for resources, e.g. natural resources, and 
the "environmental resistance" will also result from the attitude of the residents of the area to visitors, etc. But the logistic equation used to describe other populations of living organisms is also an approximate resultant description of their complex interactions within the population as well as with the environment, including in many cases virtually countless numbers of co-resident organisms.

One may also ask where the tourists in the reception area come from since the logistic equation does not include migration (see Fig. 2). They appear (or disappear) there as a result of spreading information (according to the meaning of the p parameter) about the area among potential tourists (in the original logistic equation there were births and deaths instead).

Let's go back to the last element of the TALC model: the falling (or if possible, rising) $N(t)$ curve following the stagnation (or "mature") stage. It does not result from the logistic model. It might be seen as an addition to it or as a deviation from the already more or less approached steady-state. Introducing this element into the TALC model can also be interpreted as a suggestion that, for example, parameters $p$ and $K$, if the model is to describe reality, cannot be constant in the long run. Even though the area itself may remain unchanged, the sense of satisfaction of the clients themselves may change. The decrease in $N$ may also result from exceeding the tourist capacity of the area (Butler 2009). This would result in a "spiral" exacerbating this decline, including environmental problems and the lack of space, and consequently the emergence of new competitive reception areas (Butler 2006; Russo 2002; Butler 2009). But competitive areas can also arise independently. In order to avoid the decline caused by competition with them, according to Butler, the area should be "rejuvenated" in advance, making it more attractive for tourists (Butler 2011). This is analogous to the "Red Queen hypothesis" on the co-evolution of species: the area must constantly rejuvenate to cope with the emerging competition. Otherwise, it will regress. Issues related to this phase will be further discussed in the next section.

\section{Further links between the TALC model and ecology}

An elementary assumption of the logistic model of population growth states that populations of living organisms are regulated, which allows them to persist, i.e. prevents them from extinction, as well as from exceeding certain population limits (Den Boer and Reddingius 1996). It is then assumed that so-called regulating factors and mechanisms exist (Den Boer and Reddingius 1996; Krebs 2011), depending on the density of the population with which the growth of the population is negatively related. These populations would be "self-regulating" (Odum 1982). In the last century, these issues were the subject of controversy in ecology. It has been debated whether such a relationship actually exists (Begon, Mortimer, and Thompson 1999). According to, for example, the concept of Andrewartha and Birch (Andrewartha and Birch 1954; Odum 1982; Begon, Mortimer, and Thompson 1999) the density-dependent regulating factors are less relevant, while other environmental factors such as e.g. weather and resource availability are important. Thus, populations would grow exponentially, but this increase would be interrupted from time to time by catastrophic events that would be independent on population density, that would reduce the population size, followed by exponential growth again (Andrewartha and Birch 1954; Vandermeer 1981). Adopting the logistic equation in the TALC model means also adopting - at least to the extent that it is used there - the underlying assumptions for describing the number of tourists in the reception area, i.e. that this tourist population is also governed by factors dependent on density. However, one could perversely argue, following the aforementioned ideas of Andrewartha and Birch, that the tourist population in the reception area (as well as the entire area) "develops" mainly in connection with oth- 
er than intrapopulation factors, such as exchange rates, the socio-economic situation at home and abroad, communication, availability of drinking water), competition with other reception areas, etc., adding weather factors and possible extreme situations already mentioned, such as "Egyptian plagues" in the case of Karnak. At that time, however, the logistic model to describe the tourist population would not be applicable.

The consequence of adopting the logistic model and the S-shape curve in the TALC model is also quite a surprising conclusion. It can be asked what is the relationship between the rate of changes $N$ per statistical tourist and the size of the population $N$. This rate, expressed by $(d N / d t) / N$, can be interpreted, for example, as the per capita rate of "recruiting" tourists to the area (Szeligiewicz 2008; 2010b), or as a measure of "multiplying" (or reducing) of the tourist population by one tourist (since Butler's assumption is made that the righthand side of the logistic equation would have this kind of significance), or as the average tourist satisfaction (Cole 2012). The graph of the sought dependence is therefore the graph of the right side of the logistic equation in the coordinate system with the axes $N$ and $1 / N(d N / d t)$ (Fig. $4 \mathrm{~b})$. As already mentioned above, when discussing the logistic equation, the right-hand side of the equation is a linear function of $N$, the plot of which is the descending ray. It is, therefore, a graphic interpretation of the assumption introduced in ecology into the logistic equation that as $N$ increases, the per capita rate of population growth decreases, i.e. that the density-dependent effect weakens the per capita growth of the population (and even at high densities it leads to population decline). A similar relationship exists in the TALC model, however, here Butler has argued that in the area occupied by tourist populations with ever-increasing numbers of $N$ s, certain processes that make up the "evolution" (using the Butler's nomenclature referring to the scenario of these activities) of the tourist reception area take place, the names of which he assigned to the following fragments of the S-shaped curve. This evolution is related to the "pumping" money and other investments, including organizational, in this area, as well as figuratively speaking: "in tourists" along with the development of institutionalization (Butler 1980) of services, improvement of accessibility, creation of larger and larger centres, in short with the commercialization of the tourist reception area. Initially, the proverbial cottages and huts existing in the area are replaced by hotels and other tourist centres (Butler 1980). This is introduced as the area is saturated with tourists, for better competition for them, for the "multiplication" of subsequent tourists. They seem to act as a reversed density-dependent effect, i.e. they could be expected to increase the positive perception of the area among tourists and thus accelerate the recruitment of further tourists - at least at some stage of population growth. As $N$ increases according to the TALC model in the area, efforts are undertaken to increase the efficiency of tourist service and the attractiveness of this area.

"Evolution" of the area for the chart shown in Fig. $4 \mathrm{a}$ and $\mathrm{b}$ is manifested by the changes in the area foreseen by the TALC model, together with the shifting along the line shown in the graph from small $N$ towards increasing values up to the saturation level $K$, with a simultaneous decrease in the rate of changes $N$ per capita (omitting, for now, the last stage of this evolution). Cole (2012) also points to the decline in tourist satisfaction expressed in the right-hand side of the logistic equation. The announced surprising conclusion from this model would therefore be that the primary area is the most attractive, one could figuratively say in the "virgin" phase, as it is characterized by the highest per capita growth of the tourist population (values close to $r$ ) (Fig. 4b). The decrease in attractiveness shown in Fig. 4b, paradoxically occurs, despite the simultaneously introduced investments, according to the TALC model scenario, i.e. they do not reverse this trend. Moreover, this decrease is linear, as in the case of the population 
regulated by the density-dependence ratio proposed by Verhulst in the simplest, linear form. One could, therefore, paraphrase a well-known saying that "dogs bark and caravans carry tourists to and from the destination area in such a way that the changes in density there follow a logistic model", at least to a certain point of breakdown suggested by the Butler after reaching stagnation. Quoting Plog (1972, after Butler 1980) "...destination areas carry with them the potential seeds of their own destruction, as they allow themselves to become more commercialized and lose their qualities which originally attracted tourists".

The analysis of the TALC model and Fig. $4 \mathrm{~b}$ leads to further conclusions and analogies. This is because the initial phase of small $\mathrm{N}$ and large $(\mathrm{dN} / \mathrm{dt}) / \mathrm{N})$ called in the TALC model the exploration phase, in which small groups of tourists discover, perceive and appreciate significantly different and unique values of the area without a significant impact on the economic and social relations in this area (Butler 1980) could be interpreted as a substitute for ecotourism (in line with the meaning of this term adopted in tourism), and the saturation phase (consolidation and stagnation) as a phase of mass tourism. This phase in the TALC model is known to be characterized by various environmental, social and economic problems (Butler 1980; Cole 2012).

Based on the logistic model, well-known American researchers - ecologist Robert MacArthur and biologist Edward Wilson (MacArthur and Wilson 1967; Pianka 1981; Vandermeer and Goldberg 2003) introduced the concepts of $r$ and $K$ strategies in ecology (Chapman and Reiss 2009), also known as adaptive development strategies (Faurie et al. 2012), reproductive strategies and the $r$ and $K$ continuum (Colinvaux 1986), species $r$ and $K$ (Townsend, Begon, and Harper 2003) or selection $r$ and $K$ (Pianka 1981). Having these notions briefly and caricatured, it can be said that the $r$ strategy is characterized, inter alia, by weak intra-species competition, low population densities, the small size of offspring, their high number and low survival rate, while the strategy $K$ refers to a situation of strong competition, greater investment in descendants, their large size and higher survival rate, but their small number (Pianka 1981). In the TALC model, if one looks at the tourism reception area from the perspective of tourism service providers, one can try to see some similarities to the $r$ and $K$ strategies. The suppliers operating there compete for tourists. Suppliers who have faster growth of tourists have a chance to expand their area of activity and reproduce it. At the beginning of the development of the area, investments in the area and in tourists were low, while the per capita rate of "multiplication" or attracting tourists to the area was the highest - the highest values of $(d N / d t) / N$ (the initial fragment of the straight line in Fig. 4b) Therefore, simple and cheap suppliers could quickly duplicate their activities (strategy $r$ ). When the area is saturated with tourists, i.e. with $N$ values close to the equilibrium $K$ (a fragment of the straight line near the $K$ value in Fig. 4b), competition among suppliers for tourists within the area is high compared to the area's initial development period. There is little attraction of tourists per capita caused by the lower attractiveness of the whole area, among others due to the decline in its natural values (possibly also due to competition with other external areas). Suppliers have to spend more to attract tourists. Despite this fact, the attraction of tourists to individual suppliers is decreasing. The duplication of activities of individual suppliers in this phase is slowed down ( $K$ strategy) and slower as $N$ grows.

The same phenomenon of the transformation of the tourist reception area, in short, from the phase of many cheap, small tourism service providers to the phase of providers that are less numerous, but larger and better equipped, can also be looked at through the ecologically known rule of self-thinning of plants, also applied to settled animals (Weiner 2012). Self-thinning (Vandermeer and Goldberg 2003; Chapman and Reiss 2009; Begon, Mortimer, and Thompson 1999; Krebs 2011) results 
from an intra-species competition for space and resources related to it. It is a manifestation of the monopolization of these resources. According to this rule, the average size of organisms in a population (measured e.g. by their size or masses) is a decreasing function of population density. As a result, as time passes and as the population density decreases resulting in some of them dying out, the growth of individuals in the population varies in such a way that fewer individuals remain, but with larger sizes. In the case of the tourist reception area, monopolising the space can be treated as monopolization of natural resources and services in the area for which tourists come here.

The TALC model, similarly to the logistic model in ecology, contains a regulatory mechanism described by negative feedback between the rate per capita of population growth and population size. In other words, the logistic equation contains a vision of nature according to which the fewer individuals in a population, the greater the population growth per individual, and the increase in the density of individuals slows down this rate. Thus, the fewer individuals in the population, the greater the reproduction and survival of the individuals (figuratively speaking, the better for them). Similarly, as mentioned above, according to the TALC model, the fewer tourists, the greater their satisfaction. It turns out, however, that populations in nature do not necessarily have to be present in the maximum possible spatial distribution, such as in the case of territorial behaviour (Odum 1982). On the contrary, a cluster distribution of individuals is often observed (Odum 1982), that is, when individuals of a population function, even for a certain part of their lives, in groups. This can be explained, for example, by the occurrence of intraspecific cooperation and social interactions (Odum 1982; Begon, Mortimer, and Thompson 1999), which at small population sizes may be more significant than the crowding effects (Courchamp, Clutton-Brock, and Grenfell 1999; dos Santos, Ribeiro, and Martinez
2015). At low densities, when the cooperation is low, some populations may grow less and even extinct (Krebs 2011). These phenomena were researched by the American ecologist Warder Clyde Allee (Allee 1931, after Odum 1982), hence they are called Allee effect. Many mathematical records in ecological literature take this effect into account (Hastings 1997; Courchamp, Clutton-Brock and Grenfell 1999; Murray 2001; dos Santos, Ribeiro and Martinez 2015), usually consisting of simple modifications to the logistic equation (dos Santos, Ribeiro and Martinez 2015). Similar considerations for the TALC model were conducted by Cole (2012). He focused on the processes taking place in the area of tourist reception, which contribute to positive feedback (such processes that can be called the inversed density-dependent effect have already been mentioned). He proposed that these processes should dominate at least until a certain stage of the development of the area, i.e. that their satisfaction (expressed as the value of $(d N /$ $d t) / N$ ) increases with the increase in tourist density, and then the negative crowding effect would begin to prevail. Then, in this respect, the population would behave as suggested by the logistic equation. In line with these assumptions, he modified this equation in the TALC model.

A characteristic attribute of the logistic equation is the postulated saturation of the environment with individuals from the population that inhabits it, the so-called the upper asymptote of the population size, more often referred to as the level of the habitat capacity or carrying capacity (represented by the $K$ parameter in this equation). It seems that it is thanks to this equation and its popularity that the notion capacity of the habitat has acquired the status of one of the basic concepts in ecology, although some authors consider it not very fruitful (Den Boer and Reddingius 1996). Its meaning seems obvious, especially when one looks at the solution of this equation in the form of an S-shaped curve. However, the application of this concept in practice is no longer so simple(Den Boer 
and Reddingius 1996; Seidl and Tisdell 1999). As a result, there are many definitions of what should be understood in practice by this term (Seidl and Tisdell 1999; Hui 2015). These dilemmas are also transferred to the field of tourism, where nevertheless the concept is widely used in various contexts, especially in activities aimed at protecting nature and the environment. Certainly, the logistic equation incorporated into the TALC model again contributed to its promotion.

Perhaps the most intriguing element in the TALC model is the enigmatic last fragment of the curve representing the relation between the size of the tourist population and the passage of time (Fig. 4a). It does not indicate an asymptotic approach of the population to a state of equilibrium, as it was the case with the logistic model, but it shows from a certain point on the graph a trajectory deviating from this state. Thus, the TALC model predicts that although the tourist destination and the tourist population enter the stage of stagnation, the stage of "maturity", during this period, there may appear some other unspecified circumstances, including those external to the modelled population, which change this course. Butler suggests that they will most often result in a decline in population size (Butler 2012). Such a scenario assumed in the model brings to mind the already mentioned concept of regulating the population by Andrewartha and Birch (1954). However, in the TALC model, there is density-dependent regulation, at least until the external factor is applied. If this regulation continues to function, and if the destabilizing factor is episodic, then once it has ceased, the population should return to the state of equilibrium on its own, which is due to the properties of the solution to the logistic equation. Therefore, the necessity to "rejuvenate" and innovate the area suggested by Butler to increase its attractiveness as a remedy for such a decline would not arise. Anyway, after such a "catastrophe" another area "life cycle" would appear (which fully justifies the presence of the word "cycle" in the name of the TALC model).

\section{Conclusions}

Recognizing the possible occurrence of "boom and bust" cycles in the TALC model is a challenge for further developing the way of description of the tourist reception area and the related tourist population. For example, Butler (2009; 2011) indicates that the tourist population is not homogeneous, and, if only because of that, it should be described in many cycles. He also mentions the presence or emergence of competing reception areas as possible reasons for the decline in the tourist population. He also draws attention to the need to take into account spatial effects. It seems that many of these issues can be found in the population ecology, especially in its mathematical form. The cyclical nature of the tourist population suggested by Butler can be described, for example, by the differential logistic equation, well known in ecology (Szeligiewicz 2008; Cole 2009), which leads not only to oscillation but to deterministic chaos as well. This phenomenon is modelled in ecology also through other mechanisms, such as time delays, interspecies interactions (including competition among populations), or through the use of individual-based models (Uchmański 1985, 1992; Murray 2002). Attempts are already being made to apply individual-based modelling in the field of tourism (Johnson and Sieber 2010; Szeligiewicz 2010b).

The alleged collapse of the reception area in the TALC model (as well as the one actually observed in the reception areas) indicates that the mere regulation of the population through the density-dependent effect - if it really occurs - may not be sufficient. Population models in ecology are also built to study the sustainability of a single population as well as of larger ecological systems to facilitate the answer of what factors may be responsible for this. At the same time, these issues are also of fundamental importance in tourism, and in particular in the management of tourist reception areas. Especially when the aim of this management is sustainable tourism.

The discussion on the relation between the TALC model and ecology, especially 
through the prism of the logistic model used in it, requires touching on many areas in this branch of science. In all these fields a lot of observations, theories and research has been gathered. They can provide a basis for introducing and developing new concepts and tools in tourism.

\section{Bibliography}

Alonso-Almeida, María-del-Mar, Cristóbal Fernández Robin, María Soledad Celemín Pedroche, Paulina Santander Astorga. 2017. „Revisiting green practices in the hotel industry: a comparison between mature and emerging destinations." Journal of the Cleaner Production 140: 1415-1428.

Andrewartha, Herbert George, and Louis Charles Birch. 1954. The distribution and abundance of animals. Chicago: University of Chicago Press.

Begon, Michael, Martin Mortimer, i David J. Thompson. 1999. Ekologia populacji. Studium porównawcze zwierzat $i$ roślin. Warszawa: Wydawnictwo Naukowe PWN.

Brougham, Jim, and Richard W. Butler. 1972. "The applicability of the asymptotic curve to the forecasting of tourism development." Paper presented to the Research Workshop, 4th Annual Conference of Travel Research Association (Quebec City: Jun 1972).

Butler, Richard W. 1980. „The concept of a tourist area cycle of evolution: implications for management of resources." Canadian Geographer 24(1): 5-12.

Butler, Richard W. 2009. „Tourism in the future: cycles, waves or wheels?" Futures 41(6): 346-352.

Butler, Richard W. 2011. Tourism area life cycle, Contemporary Tourism Reviews. Oxford: Goodfellow Publishers.

Butler, Richard W. 2012. „Mature tourist destinations: can we recapture and retain the magic." In Renovación y reestructuración de destinos turísticos en áreas Costeras: Marco de análisis, procesos, instrumentos y realidades, edited by José F. V. Rebollo and Israel R. Sánchez, 19-36. Valencia: Universidad de Valencia.

Casasnovas, Antonio L. A., and Andreu Sansó Rosselló. 2009. The tourist area lifecycle and the unit roots test. A new economic perspec- tive for a classic paradigm in tourism. Accessed February 14, 2018. https://ideas.repec.org/p/ubi/deawps/38.html.

Chapman, Jenny L., and Michael J. Reiss. 2009. Ecology. Principles and applications. Cambridge: Cambridge University Press.

Chapman, Royal N. 1928. "The quantitative analysis of environmental factors." Ecology 9(2): 111-122.

Cole, Sam. 2012. „Synergy and congestion in the tourist destination life cycle." Tourism Management 33(5): 1128-1140.

Colinvaux, Paul. 1986. Ecology. New York: John Wiley \& Sons.

Courchamp, Franck, Tim Clutton-Brock, and Bryan Grenfell. 1999. „Inverse density-dependence and the Allee effect." Trend in Ecology and Evolution 14(10): 405-410.

Den Boer, Pieter J., and Joannes Reddingius. 1996. Regulation and stabilization paradigms in population ecology. London: Chapman \& Hall.

dos Santos, Renato Vieira, Fabiano L. Ribeiro, and Alexandre Souto Martinez. 2015. „Models for Alee effect based on physical principles." Journal of Theoretical Biology 385: 143-152.

Doubleday, Thomas. 1853. The true law of population shewn to be connected with the food of the people. London: Smith, Elder.

Egerton, Frank N. 1973. „Changing concepts in the balance of nature." Quarterly Review of Biology 48: 322-350.

Faurie, Claude, Christiane Ferra, Paul Médori, Jean Dévaux, and Jean-Louis Hemptinne. 2011. Écologie. Approche scientifique et pratique. Paris: TEC \& DOC Lavoisier.

Foryś, Urszula. 2005. Matematyka $w$ biologii. Warszawa: Wydawnictwo Naukowo-Techniczne.

Gliwicz, Joanna. 2010. „Nieprzewidywane skutki ocieplenia klimatu: śnieg - norniki - bioróżnorodność." Problemy Ekologii 14: 121-125.

Hastings, Alan. 1997. Population Biology. Concepts and models. New York: Springer.

Johnson, Peter A., and Renee E. Sieber. 2010. "An individual-based approach to modelling tourism dynamics." Tourism Analysis 15(5): 517-530.

Krebs, Charles J. 2011. Ekologia. Warszawa: Wydawnictwo Naukowe PWN.

Lundtorp, Svend, and Stephen Wanhill. 2001. 
„The resort lifecycle theory. Generating processes and estimation." Annals of Tourism Research 28(4): 947-964.

Ma, Mulan, and Robert Hassink. 2013. „An evolutionary perspective on tourism area development." Annals of Tourism Research 41: 89-109.

MacArthur, Robert H., and Edward O. Wilson. 1967. The theory of island biogeography. Princeton: Princeton University Press.

Murray, James D. 2002. Mathematical biology. I: An introduction. Berlin: Springer.

Nicholson, Alexander J. 1954. „An outline of the dynamics of animal populations." Australian Journal of Zoology 2(1): 9-65

Nicholson, Alexander J., and Victor A. Bailey. 1935. „The balance of animal populations. Part I." Proceedings of the Zoological Society of London 105(3): 551-598. https://doi. org/10.1111/j.1096-3642.1935.tb01680.x.

Odum, Eugene P. 1982. Podstawy ekologii. Warszawa: Państwowe Wydawnictwo Rolnicze i Leśne.

Pahl-Wostl, Claudia. 1995. The dynamic nature of ecosystems. Chaos and order entwined. Chichester: John Wiley \&Sons.

Papatheodorou, Andreas. 2004. „Exploring the evolution of tourism resorts." Annals of Tourism Research 31(1): 219-237.

Pianka, Eric R. 1981. Ekologia ewolucyjna. Warszawa: Wydawnictwo Naukowe PWN.

Prideaux, Bruce. 2000. „The resort development spectrum - a new approach to modeling resort development." Tourism Management 21(3): 225-240.

Rodríguez, Juan Ramón Oreja, Eduardo Parra-López, and Vanessa Yanes-Estévez. 2008. "The sustainability of island destinations: Tourism area life cycle and teleological perspectives. The case of Tenerife." Tourism Management 29(1): 53-65.

Russo, Antonio Paolo. 2002. „The "vicious circle” of tourism development in heritage cities." Annals of Tourism Research 29(1): 165-182.
Rose, Michael R., 1987. Quantitative ecological theory: an introduction to basic models. London \& Sydney: Croom Helm.

Seidl, Irmi, and Clem A. Tisdell. 1999. „Carrying capacity re-considered: from Malthus' population theory to cultural carrying capacity." Ecological Economics 31(3): 395-408.

Singh, Sagar. 2011. „The tourism are "life cycle”: a clarification. Research notes and reports." Annals of Tourism Research 38: 1178 - 1187.

Szeligiewicz, Wojciech. 2008. „Samoistne' fluktuacje ruchu turystycznego - rozważania teoretyczne." Turystyka i Rekreacja 4: 13-18.

Szeligiewicz, Wojciech. 2010a. "Chaos, duch Laplace'a i ekologia." Wiadomości Ekologiczne 56(2): 45-65.

Szeligiewicz, Wojciech. 2010b. „Poszukiwanie zjawisk emergentnych w ruchu turystycznym poprzez jego modelowanie osobnicze." Turystyka i Rekreacja 6: 63-71.

Townsend, Colin R., Michael Begon, and John L. Harper. 2003. Essentials of ecology. Malden: Blackwell Publishing.

Uchmański, Janusz. 1985. „Differentiation and frequency distributions of body weights in plants and animals." Philosophical Transactions of Royal Society London, Ser. B, 310(1142): 1-75.

Uchmański, Janusz. 1992. Klasyczna ekologia matematyczna. Warszawa: Wydawnictwo Naukowe PWN.

Vandermeer, John. 1981. Elementary mathematical ecology. New York: A Wiley-Interscience Publication.

Vandermeer, John H., and Deborah E, Goldberg. 2003. Population ecology. First principles. Princeton: Princeton University Press.

Verhulst, Pierre François, et al. 1838. „Notice sur la loi que la population suit dans son accroissement." Correspondance Mathématique et Physique 10: 113-121.

Weiner, January. 2012. Życie i ewolucja biosfery. Warszawa: Wydawnictwo Naukowe PWN. 